\title{
GIOVANNI I ABDON PAMICH - POVIJEST KAO SUDBINA ILI “ISPRAŽNJENO MJESTO” U RIJEČKOJ MEDICINSKOJ HISTORIOGRAFIJI
}

\author{
GIOVANNI AND ABDON PAMICH - HISTORY \\ AS DESTINY OR "EMPTY PLACE" IN \\ RIJEKA MEDICAL HISTORIOGRAPHY
}

\author{
Marinko Lazzarich*
}

\begin{abstract}
SAŽETAK
Riječka medicinska povjesnica bogata je riznica događaja, znamenitih ličnosti $i$ vrijednih inovacija u području zdravstva. Geopolitički položaj grada granice s višekulturnim stanovništvom uvelike su determinirali povijesni razvoj Rijeke, obilježen snažnim sukobima interesa i brojnim identitetskim previranjima. Veliki egzodus domicilnoga stanovništva talijanske nacionalnosti nakon Drugoga svjetskog rata bitno je promijenio socijalnu sliku grada. Medu brojnim esulima našli su se Giovanni (I932.) i Abdon Pamich (I933.), braća čiji život podsjeća na sudbinu mnogih raseljenih Riječana koji su po završetku rata bili primorani na život u egzilu. Napustivši rodni grad u formativnim godinama svoga djetinjstva, u Italiji su ostvarili uspješnu karijeru u području medicine i zdravstva. Stariji brat Giovanni postao je uspješan kirurg, a mlađi Abdon psiholog. Osim što je bio šef opće kirurgije u bolnicama Monfalconea $i$ Gorizije, Giovanni Pamich predavao je na Sveučilištu u Trstu. Abdon Pamich je u području sportske psihologije suradivao s ponajboljim talijanskim tenisačicama, a bio je i psiholog rukometne reprezentacije Italije. Obojica su se bavila atletikom. Abdon Pamich je osvojio srebrnu medalju u brzom hodanju na europskom prvenstvu u Švedskoj 1958. i zlatnu medaliu na Olimpijskim igrama u Tokiju 1964.
\end{abstract}

Adresa za dopisivanje: Marinko Lazzarich, Sveučilište u Rijeci, Učiteljski fakultet, Sveučilišna avenija 6, 51000 Rijeka, Hrvatska.

ORCID ID: https://orcid.org/0000-0003-1401-9610.

E-pošta:marinko.lazzarich@uniri.hr. 
Osim postignuća dvojice braće na polju medicine, u ovom se radu problematizira i pozicija emigranta, koja dolazi do izražaja u knjizi Abdon Pamich, memorie di un marciatore (Pordenone, 2016.) Roberta Covaza, uzbudljivoj biografiji riječkoga esula. Istražuje se koncept tematizacije ograničenja razlike i iskustva migracije stanovnika Rijeke suočenih s egzistencijalnim pitanjem.

Ključne riječi: Giovanni i Abdon Pamich, medicina, psihologija, migracija, atletika, povijest Rijeke, Italija

\section{UvoD}

Grad Rijeka kao urbani entitet granice postaje zanimljiva istraživačka tema. Promišljajući o gradskom prostoru u literaturi Lehan zaključuje kako u dugačkome vremenskom razdoblju posljednjih nekoliko stoljeća grad ima značajnu ulogu u ljudskoj sudbini. ${ }^{1}$ Prema Lehanu, grad stvara vlastiti povijesni ritam iako se njegova stvarnost s vremenom rekonstruirala i transformirala. Stoga urbani prostori moraju biti neprestano preispitivani jer se kroz prizmu grada može interpretirati prevrtljiva prošlost. Povijesno lice višekulturne Rijeke opipljivo je svjedočanstvo o mnogim poznatim ličnostima, pripadnicima različitih nacionalnosti. Lučki je grad tijekom povijesti doživljavao mnogobrojne društveno-političke promjene u obliku kolektivnih varijacija identiteta. ${ }^{2}$ Geopolitičkom pozicijom nestabilnoga graničnog područja s višeetničkim stanovništvom, Rijeka je često bila prizorište identitetskih sukoba. Riječani su najčešće bili svjedoci događaja u koje su silom bili uvučeni, stoga se grad na Kvarneru nadaje kao poticajan prostor za raspravu o drugima. Suživot Riječana različitih nacionalnosti oduvijek je bio determiran prisutnošću mora jer "na vodi percepcija drugoga postaje istančanijom, kao da je pojačana zajedničkom i istodobnom uzajamnom opasnošću."

Dvadeseto je stoljeće razdoblje najradikalnijih političkih promjena u gradu. ${ }^{4} \mathrm{U}$ međuraću se Rijeka/Fiume nalazi u sklopu Kraljevine Italije. Završetkom Drugoga svjetskog rata dolazi do promjene istočne granice

Lehan, Richard (1998). City in Literature: an intelectual and cultural history, Berkeley, Los Angeles; University of Press.

2 Posljednjih se godina pojam identiteta našao u središtu diskurzivne eksplozije. Vidi u: Hall, Stuart (1996). Who Needs Identity, in: Hall, Stuart, du Gay, Paul ed., Questions of Cultural Identity. Sage, London, 1. Proces dekonstrukcije nacionalističkoga diskursa otvara nove vidike u kontekstu politike identiteta.

3 Brodski, Iosif (1992). Watermark, New York; Noonday Press; Farrar, Straus \& Giroux, 34.

4 Nakon Prvoga svjetskog rata, pripavši Kraljevini Italiji, Rijeka je politički i ekonomski ostala izolirana u odnosu na Apeninski poluotok. U međuratnom je razdoblju riječka društvena i kulturna klima na talijanskom jeziku veoma živa pa se može govoriti o svojevrsnome separatnom tijelu (corpo separato) u hrvatskome kulturnom okružju. 
Italije. Bila je to dramatična promjena: grad su početkom svibnja 1945. zauzele jugoslavenske trupe i odmah je započela žestoka represija koja nije bila usmjerena samo prema fašistima već općenito prema građanima talijanske nacionalnosti, posebice autonomašima i svima koji su se protivili jugoslavenskoj aneksiji. ${ }^{5}$ Politički sporazumi i sociološki pritisci tadašnjih susjednih država dovode do masovnoga iseljavanja talijanskoga stanovništva iz Istre i Rijeke. ${ }^{6}$ Utjecaj nove jugoslavenske državne vlasti bio je pritom presudan. Ideologija novouspostavljene države nije bila puki odraz ratnoga iskustva. "Iskustvo nasilja strukturira ideologiju iskustva na takav način da ideologija, zauzvrat, strukturira iskustvo."”

Rijeka iz temelja mijenja svoju demografsku strukturu budući da tridesetak tisuća većinskoga talijanskog dijela stanovništva (od 50 ००० građana koliko ih Rijeka ima 1945.) napušta grad na Kvarneru. ${ }^{8} \mathrm{U}$ socijalističkoj Jugoslaviji osim radničke klase svi ostali postaju "neprijatelji naroda". Deklariranu politiku "bratstva" i autonomije talijanskoga pučanstva ubrzo smjenjuje homogenizacija i politika željezne šake, što rezultira lošim odnosom između građana i nove narodne vlasti. ${ }^{9}$ Kolektivna objava nepripadnosti nagnala je uglavnom Riječane talijanske nacionalnosti na napuštanje okupirane zemlje i potragu za još jednom domovinom, ne razmišljajući kako se režimi mijenjaju, a narodi ostaju. ${ }^{10}$ Dotad većinsko stanovništvo, nositelj svih mehanizama gradskoga života, nije percipiralo mogućnost da se u perspektivi politička situacija može promijeniti, niti da talijanska kultura može značajnjije utjecati

Pupo, R. (2018). Fiume città di passione, Laterza, Roma-Bari.

6 Tzv. veliki egzodus stanovništva talijanske nacionalnosti iz Dalmacije, s otoka, iz Rijeke i Istre trajao je dvanaest godina, od 1945. do 1956. Prethodio mu je „crni egzodus“, kako ga nazivaju talijanski povjesničari, nakon kapitulacije fašističke Italije u rujnu 1943. Vidi u: Petacco, Arrigo (1999). L'esodo, La tragedia negata degli italiani d'Istria, Dalmazia e Venezia Giulia, Milano; Mondadori; Pupo, Raoul (2005). Il lungo esodo, Istria: le persecuzioni, le foibe, l'esilio, Milano; Rizzoli. Riječ je o Talijanima koji nisu htjeli ostati unutar granica nove države Jugoslavije.

7 Parnell, P. C. (1992), Time and Irony in Manila Squatter Movements, in: Nordstrom, Carolyn, Martin Joann eds., The Paths to Domination, Resistance and Terror, University of California Press, Berkley, 139.

8 Sam čin iseljenja domicilnoga stanovništva različito je interpretiran s dviju strana obala Jadrana. (Samo)izbor odlaska u susjednu zemlju neki su hrvatski povjesničari i publicisti nazvali samoizgnanstvom. Vidi u: Fabrio, Nedjeljko (2003). Ruža vjetrova, sjevernojadranski $i$ drugi eseji, Zagreb; Naklada Ljevak, 354.

9 Opterećeni brojnim političkim i birokratskim poteškoćama na odlazak se ne odlučuju samo simpatizeri bivšega režima već i djelatnici u javnim službama, privatnici, trgovci bez posla, pomorci, obrtnici i radnici koji ne prihvaćaju novouspostavljeni poredak. (Pupo, 2018).

10 Pedesete su godine mukotrpna oporavka Italije zbog čega je život esula (tal. esule = prognanik) bio dodatno otežan jer je u novoj domovini samo pojačan njihov osjećaj nepripadnosti. 
na slavenski svijet u obliku poticanja snošljiva suživota. U Rijeci ostaje tek manjina koja će u slavenskom okružju nastojati očuvati talijansku kulturu.

Radikalni politički obrati neizbježno su se odrazili na životne sudbine mnogobrojnih znamenitih Riječana. U tekstu se govori kako o kolektiunom sjećanju, tako i o pojedinačnom. Kolektivno sjećanje sadrži zanimljivu karakteristiku - "kontrolu pamćenja koja uvjetuje današnju hijerarhiju moći."11 Također, riječ je o društvenim procesima „koje pisana povijest ne bilježi i ne analizira."12 Krajem dvadesetoga stoljeća brojni su povjesničari promicali mikropovijesnu istraživačku metodu ${ }^{13}$ koja je usredotočena na proučavanje povijesti „odozdo“, tj. od istraživanja povijesnih okolnosti i činjenica na razini lokalnog i individualnog. ${ }^{14}$

Pojedinci u povijesnim previranjima nerijetko postaju instrument kolektivnoga ludila u trenucima kada se briše granica između individualnog i kolektivnog identiteta. ${ }^{15}$ Kako je riječ o konfliktnim vrijednostima (jer identitet nije neutralna vrijednost), a konflikti se redovito iz javnog reflektiraju i na intimni život, posljedice nacionalne zaluđenosti uvijek su bolne - i za društvo i za pojedinca. ${ }^{16}$ Individualna sjećanja, stoga, nadilaze kontrolu pamćenja ${ }^{17}$, što se može promatrati i u slučaju riječke obitelji Pamich. Život braće Pamich, Giovannija i Abdona, podsjeća na sudbinu mnogih raseljenih Riječana koji su odlučili živjeti u egzilu. Njihova je biografija puna začudnih, istodobno i zanimljivih detalja, uspona i padova, poput života mnogih njihovih sugrađana širom svijeta. Napustivši rodni grad u formativnim godinama svoga djetinjstva, obojica su u Italiji ostvarili uspješne karijere u području medicine i zdravstva.

\section{Connerton, Paul (2004). Kako se društva sjećaju, Zagreb; Izdanja Antibarbarus, 5-6.}

12 Rihtman-Auguštin, Dunja (1988). Etnologija naše svakodnevice, Zagreb; Školska knjiga, 13. Specifičan položaj povijesnih i geopolitičkih previranja u Rijeci idealna je književna tema za razvijanje kulturnoga dijaloga. U egzilni korpus riječke književnosti koja propituje mogućnosti humane komunikacije s drugim do izražaja dolaze bolne teme poput doživljaja raseljenosti i sudbine onih koji su se odlučili ostati u rodnome gradu.

13 Nora, Pierre (2007). Između sjećanja i povijesti, Diskrepancija, 8 (12), 135-165.; Foot, John (2009). Frature d'Italia, Milano; Rizzoli, Dukovski, Darko (2011). Istra i Rijeka u prvoj polovici 20. stoljeća: (1918. - 1947.) Zagreb; Leykam.

14 Ginzburg, Carlo (1989). Clues, Myths, and Historical Method, Baltimore; John Hopkins University Press. Istražujući život i vjerovanja talijanskoga heretika Menocchia iz mjesta Montereale Valcellino u Italiji, Ginzburg je izvršio velik utjecaj u smislu promicanja mikropovijesne istraživačke metode.

15 Pitanje identiteta i njegove tvorbe, granice identiteta koje prodiru u tkivo društva i nacije, neizbježno se odražavajući na sudbinu pojedinca. Taj dinamični fenomen identiteta konstruira se samo preko odnosa s drugim, kroz razliku i prema onom što mu nedostaje.

16 Weeks, Jeffrey (1998). The Value of Difference, in: Jonathan Rutherford ed., Identity: Community, Culture, Diference; London; Lawrence \& Wishart.

17 Connerton, P. (2004). 
Povijest medicine u Rijeci sastavni je dio opće povijesti grada na Kvarneru jer je medicina oduvijek bila važnim dijelom gospodarstvenoga i političkog života grada. ${ }^{18}$ No historiografija se uglavnom bavi općeprihvaćenim veličinama. Cilj je ovoga rada svojevrsna dopuna službene riječke medicinske historiografije upućivanjem na značajne ličnosti koje su svojim korijenima povezane s gradom na Rječini, kao i valorizacija njihovih prinosa u području zdravstva. Osim medicinskih postignuća, u tekstu se problematizira motiv raseljenosti apostrofiran u knjizi Roberta Covaza Abdon Pamich, memorie di un marciatore (EBI, Pordenone, 20I6.) u kontekstu pogranične literature. Propituje se koncept tematizacije ograničenja razlike $\mathrm{i}$ iskustva migracije stanovnika Rijeke suočenih s egzistencijalnim pitanjem. Nastoji se proniknuti i u moguću ulogu prvobitne zavičajnosti u profiliranju osobnosti Abdona i Giovannija Pamicha.

\section{Povijesne intruzije I RIJEČKA MEdicina U DVADESETOM STOLjEĆU}

Povijesni je okvir veoma važan u analizi i interpretaciji „mjesta sjećanja“, kako to tumači francuski povjesničar Pierre Nora. Kolektivna mjesta i „mjesta sjećanja“ su „ponajprije ostaci, ultimativni oblik u kojem preživljava komemorativna svijest u povijesti koja sjećanje treba jer ga se odrekla“19 Iskustva pojedinaca i njihove proživljene spoznaje o povijesnim intruzijama u određenom prostoru svojevrstan su mehanizam dekonstrukcije službene "školske" povijesti ili sadržaja "objektivnih" povijesnih zapisa. Supostojanje službene ,školske“ povijesti i alternativne "usmene“ povijesti (u obliku memorata, usmenih priča) posebice dolazi do izražaja u nekim znanstvenim područjima, poput etnografije i folkloristike. ${ }^{20} \mathrm{U}$ kontekstu posredovanja (jedne jedinstvene) povijesne istine važno je pitanje razlikovanje literature i dokumenata, poput razlikovanja službene i usmene povijesti. Brojni povjesničari, kulturolozi i antropolozi ${ }^{21}$ zagovaraju tezu o recepcijskoj važnosti autobiografske literature koja moralnom snagom doživljenoga stavlja pod znak

18 Muzur, Amir (2013). Nezavršena povijest medicine u Rijeci. Priča o gradu, ljudima i profesiji, Rijeka; Medicinski fakultet Sveučilišta u Rijeci, Hrvatsko znanstveno društvo za povijest zdravstvene kulture, Naklada Kvarner.

19 Nora, P. (2007), 143.

20 Jambrešić-Kirin, Renata (1995). Svjedočenje i povijesno pamćenje: o pripovjednom posredovanju osobnog iskustva, Narodna umjetnost - hrvatski časopis za etnologiju i folkloristiku, 32 (2), 165-185.

21 Velčić, M. (1991). Otisak priče. Intertekstualno proučavanje autobiografije, August Cesarec, Zagreb, Felman, Shoshana, Laub, Dori (1992). Testimony: Crises of Witnessing in Literature, Psychoanalysis and History, Routledge, London-New York. 
pitanja legitimitet posredovanja povijesne istine kojima se koriste službene nacionalne povijesti. ${ }^{22}$

Literatura granice oduvijek je bila tema prepuna neotvorenih poglavlja za otkrivanje drukčije stvarnosti, odvojene, ali bogate u svojoj složenosti životnih projekcija. Jedna od neiscrpnih tema riječke literature jest prisilno iseljenje domicilnoga stanovništva. ${ }^{23}$ Migracijski tokovi, bilo dobrovoljni ili prisilni, uzrokuju istodobno i krizu identiteta. Jambrešić-Kirin navodi kako su interes za migracije s pojačanim zanimanjem za lokalnu i obiteljsku povijest u funkciji otkrivanja mehanizama očuvanja identiteta, usprkos njegovim preradama u procesu prevrednovanja prošlih događaja. ${ }^{24}$

Nakon Ozimskih sporazuma mnoštvo tekstova o iseljenju i proživljenoj drami svjedočilo je o dubini jedne rane koja nije nikad posve zacijelila. ${ }^{25}$ Budući da se šezdesetih godina u Europi pojačao proces regionalnoga osvješćivanja, u talijanskome iseljeničkom krugu dolazi do kulturološke homogenizacije. Tema granice postaje simbol očuvanja razdijeljenoga nacionalnog identiteta.

Prelaskom Istre i Rijeke Jugoslaviji mnogi su stanovnici talijanske nacionalnosti preselili na Apeninski poluotok, a među emigrantima prednjačili su

22 Bhabha, H. K. (1990). Nation and Naration, Routledge, London; Jambrešić- Kirin, R. (1995).

23 Esulska književnost italofonih pisaca specifična je po svome nostalgično-optužujućem tonu: dok bivši stanovnici (mahom talijanske i mađarske nacionalnosti) Rijeku doživljavaju izgubljenim, papirnatim gradom (città di carta, Pužar, 1999), hrvatsko pučanstvo poima Rijeku prije 1945. otrgnutim i otuđenim gradom. Vidi: Fabrio, Nedjeljko, u: Berlot, Duško (ur.) (1970). Rijeka, fotomonografija, Zagreb; Grafički zavod Hrvatske (uvodni nenumerirani tekst). Doseljenicima je ona pak zamjensko utočište. Važno je istaknuti da su italofoni i ungarofoni optanti većinom bili rođeni Riječani, to je veća njihova trauma zbog prisilnoga iseljenja. Bol i nostalgija temeljne su motivske silnice, provodna nit koja se provlači u najvećem broju tekstova. Tjeskoba zbog odlaska u novu sredinu potencirana je nemogućnošću povratka pa je melankolično prizivanje prošlosti odraz spisateljskih bolnih suočavanja sa stvarnošću.

24 Renata Jambrešić-Kirin (1995) razmatra teorijsko-metodološke i moralne probleme etnografskog pristupa analizi svjedočenja kao žanra usmene povijesti i literature svjedočenja kao autobiografske proze. Propituje probleme na sjecištu antropologije, etnografije i naratologije - na koji se način osobno iskustvo upisuje u povijesno pamćenje, koje su konvencije predstavljanja i vrednovanja osobnog iskustva relevantne za pojedine zajednice i društva i njihovo reinterpretiranje povijesti.

25 Iz perspektive raseljenih Riječana izgubljeni grad ili papirnati grad postaje podatna tema za historijat nostalgije fjumane. Vidi: Bačić-Karković, Danijela (2008). Rijeka u priči: hrestomatija knjižernih tekstova o gradu na Rječini, Rijeka; Filozofski fakultet u Rijeci, Odsjek za kroatistiku. Glavno pitanje većine fikcionalnih protagonista glasi: Ostati ili otići? Talijanski doživljaj egzodusa i dvojbu koju su sudionici vremena osjećali najbolje oslikava misao Alessandra Damianija: Quelli non sapevano dove andare, io dove restare. (Oni nisu znali kamo otići, a ja gdje ostati.). Damiani, Alessandro (1996). La torre del borgo, Udine; Campanotto, 189. 
protivnici socijalističkoga političkog sustava, prvenstveno pripadnici bogatijih klasa i građanstvo, ali je val iseljavanja zahvatio i ostale socijalne kategorije. ${ }^{26}$ Među azilantima bilo je i uglednih liječnika.

U nizu partikularnih identiteta opća povijest grada Rijeke bila bi nepotpuna bez povijesti medicine. Osim što se u dvadesetom stoljeću u lučkom gradu razvija industrija, i medicina bilježi lijepe dosege. Rijeka je "zahvaljujući djelovanju dvadesetak liječnika, povremeno bila pozornicom svjetski zanimljive i inovativne medicine." ${ }^{27}$ Među riječkim medicinarima mnoštvo je značajnih ličnosti, od pionira gradske medicine Giovannija Battiste Cambierija (1754. - 1838. $)^{28}$, vrsnoga venerologa s kraja osamnaestoga stoljeća, do Vinka Frančiškovića koji je sedamdesetih godina dvadesetoga stoljeća pretvorio Kirurški odjel bolnice Dr. Zdravko Kučić u vrhunsku kliniku.

I novija povijest medicinske struke na riječkom području veoma je sadržajna. ${ }^{29} \mathrm{U}$ galeriji osebujnih ličnosti ističu se vrhunski prinosi liječnika u dvadesetom stoljeću. Početkom stoljeća bilježimo vrijedan prinos riječkoga kliničara Lionella Lenza (1872. - 1939.), primarija Gradske bolnice sv. Duha koji je svojim istraživanjima obogatio kliničku znanost i praksu, osobito svojim radovima o koreji i leukemiji. ${ }^{30} \mathrm{Uz}$ njega, u Rijeci su u to doba djelovala tri vrsna kliničara: internist i rinolaringolog Georg Catti, pedijatar Franjo Kresnik i kirurg Antonio Grossich. Liječnik i političar Grossich (I849.

26 Sequi, Eros (1953). Eravamo in tanti, Fiume / Rijeka; Edit.

27 Muzur, A. (2013), 284.

28 G. B. Cambieri diplomirao je medicinu u Paviji, došavši u Rijeku 1797. i suočivši se s neugodnom epidemijom venerične zaraze. Kao nadareni liječnik koristio se svim svojim znanjima proučavajući bolest na tisućama pacijenata u lokalnim bolnicama. Osmislio je novu metodu liječenja jedne vrste sifilisa živinim spojevima. Oporučno je 1838. donirao novac Bolnici svetoga Duha u Rijeci, što je omogućilo daljnji razvoj zdravstva u gradu. Vidi u: Gruber, Franjo, Brajac, Ines, Stanić-Zgombić, Zrinka (2008). Giovanni Battista Cambieri and the Beginning of Venereology in Rijeka Region, Acta dermatovenerologica Croatica, 16 (1), 3-7.

29 Među liječnicima koji su ostavili vrijedan trag na polju medicine polovicom dvadesetog stoljeća valja spomenuti dr. Antu Vukasa i dr. Zdravka Kučića. Ante Vukas (1910. 1991.) našao se na čelu Dermatovenerološkoga odjela na Sušaku u neugodnome ratnom razdoblju 1941. godine. Uspješno je liječio određene venerične bolesti penicilinom, primjenjivao dermoabraziju i transplanaciju kose te izumio epidermotekstoskopiju. Vidi u: Gruber, Franjo, Čabrijan, Leo, Vukas, Duje (2000). Prof. dr. Ante Vukas - pronalazač epidermotekstoskopije, Acta Facultatis medicae fluninensis, 25 (1-2), 77-78. Zdravko Kučić (1910. - 1961.) bio je dugogodišnji organizator poslijeratnoga bolničkog zdravstva grada i kotara Rijeka, obavljajući zdravstvenu službu na Internističkom odjelu sušačke bolnice. Dr. Kučić bio je jedan od zaslužnih osnivača riječkoga Medicinskog fakulteta 1955. godine.

30 Vidi u: Sepčić, Juraj, Muzur, Amir, Tomić, Zoran, Popović, Katarina (2000). Lionello Lenaz i pojam statične inervacije mišićnog tonusa, Acta Facultatis medicae fluminensis, 25, 65-66. 
- 1926.) inicirao je inovativnu tehniku preoperatvne dezinfekcije jodnom tinkturom. ${ }^{31}$

U Rijeci bilježimo početke hrvatske kardiotorakalne i transplantacijske kirurgije. Riječki su liječnici dali svjetski doprinos u području presađivanja bubrega. U sušačkoj bolnici prvi eksperimentalni kirurški postupci koji su prethodili zahvatima na ljudima počeli su I966., da bi pet godina poslije uslijedilo prvo presađivanje bubrega - u siječnju r97I. godine. ${ }^{32}$ Izveo je to liječnički tim pod vodstvom dr. Vinka Frančiškovića (1919. - 1984.). ${ }^{33}$ Dr. Frančiškoviću pripisuje se i utemeljenje riječke kardiokirurgije. Treba spomenuti i uspješan rad Radium odjela Opće bolnice dr. Sobol na čelu s dr. Viktorom Finderleom (1902. - I964.), 34 izumiteljem vakuum-ekstraktora za dovršenje poroda, kojim je ovaj riječki opstetričar stekao značajnu slavu izvan granica bivše države. Finderleov asistent i nasljednik na mjestu šefa Odjela dr. Drago Vrbanić (1912. - 1996.) primijenio je vrijedne inovacije u području ginekoloških malignoma šezdesetih godina dvadesetoga stoljeća (Pavlović, 20I3). Najnoviji inovativni doseg riječka medicina bilježi na polju invazivne kardiologije. ${ }^{35}$

U nemalom broju znamenitih, ali i povijesno nedovoljno valoriziranih ličnosti rođenih u Rijeci, pojavljuju se i liječnici svjetskoga formata poput kirurga Erika Vija ili psihijatra Giovannija Dalma. Liječnik i književnik

31 Perini, Giovanni (1949). Nel centenario della nascita di Antonio Grossich, Minerva medica, 40 (27), 1-8.

32 Posljednjih desetljeća napredak transplantacijske medicine u Rijeci rezultirao je činjenicom da je Rijeka i danas jedan od vodećih transplantacijskih centara u Hrvatskoj. Naime, Klinika za urologiju Referentni je centar Ministarstva zdravstva za transplantaciju bubrega (Fučkar i sur, 2011).

33 Vinko Serafin Frančišković pohađao je Kraljevsku klasičnu gimnaziju Giovanni Prati u Trentu. U srpnju 1943. obranio je na Medicinskom fakultetu Sveučilišta u Padovi diplomski rad o doprinosu kirurškoj terapiji fraktura femoralnoga vrata. Vidi u: Primc, Davor, Muzur, Amir, Doričić, Robert, Markić, Dean (2017). Novi prilozi o životu i radu Vinka Frančiškovića (1919. - 1984.), pionira kardiotorakalne i transplantacijske medicine u Hrvatskoj, Acta medico-historica Adriatica, 15 (1), 119-128.

34 Dr. Viktor Finderle došao je u Rijeku 1946. kao šef dislociranoga novoosnovanog odjela Rodilište i ginekologija Riječke opće bolnice, a ubrzo zatim i Rodilišta i ginekologije. Primarij Finderle potom sa svojim asistentima otvara i vodi Radium odjel u krilu Opće bolnice za cijelu širu regiju od Istre do Zadra i otoka. Uspješni je liječnik pokrenuo otvaranje Primaljske škole (do 1947. pod talijanskim nazivom Scuola d'ostetrica) u gradu. Vidi u: Uremović, Vladimir, Mirošević, Lovro, Vukelić, Ivan (2006). Razvoj primaljskog školstva u Rijeci, Acta medico-historica Adriatica, 4 (1), 85-96.

35 Krajem veljače 2019. docent Sandro Brusich je s timom svojih kolega s Odjela za invazivnu i interventnu kardiologiju prvi u Hrvatskoj ugradio najmanji elektrostimulator srca na svijetu. Predstavnik mlađe generacije riječkih intervencijskih kardiologa godišnje obavlja više od 700 složenih kardioloških intervencija. Njegova su uža područje u intervencijskoj kardiologiji elektrofiziologija i elektrostimulacija. 
Erik Vio (I9IO. - 1999.) rođen je u tipičnoj riječkoj srednjoeuropskoj obitelji čiji su članovi bili pripadnici različitih nacionalnih i kulturnih krugova. Stoga je budući kirurg još za djetinjstva i mladosti provedene u Rijeci naučio nekoliko svjetskih jezika. ${ }^{36}$ Studirao je medicinu u Rimu, nakon čega je zahvaljujući državnoj stipendiji stjecao praktično iskustvo kao kirurg u Tokiju i Šangaju. ${ }^{37}$ Po završetku Drugoga svjetskog rata dvadeset i osam godina obavljao je liječnički poziv u Hong Kongu, usavršivši kirurško umijeće i dobro upoznavši istočnjačku kulturu. Tek je povremeno svraćao u Rijeku. Geografski udaljen od rodnoga grada i upoznat s raseljenošću svojih sugrađana talijanske nacionalnosti, Erik Vio je ostao na margini interesa medicinske javnosti na ovim prostorima. ${ }^{38}$

Giovanni Dalma (1895. - 1977.) krenuo je stopama svoga oca Davida, doktora medicine, diplomiravši u Padovi I920., nakon što je kao bolničar osjetio ratne strahote u sanitetu na ruskoj fronti. Nekoliko je godina radio u riječkoj Gradskoj bolnici sv. Duha, a zatim stječe iskustvo diljem eminentnih europskih centara, da bi specijalizirao psihijatriju u Reggio Emiliji. Potom se vraća u rodni grad gdje je do kraja tridesetih godina zaposlen na psihijatrijskom odjelu Gradske bolnice. Po završetku Drugoga svjetskoga rata odlazi u Argentinu gdje se u gradu Tucumanu našao među osnivačima Medicinskoga fakulteta, vodeći u različitim razdobljima katedre za kliničku neurologiju i medicinsku psihologiju.$^{39}$ I njegova su postignuća na polju medicine nedovoljno poznata, kao i Viova. ${ }^{40}$

36 U obitelji njegova oca Antonija govorilo se talijanskim jezikom, a roditelji njegove majke Marije, rođ. Catti, služili su se isključivo njemačkim jezikom budući da se njegov djed oženio Bečankom Josephinom Rudolf. Osim uspješne liječničke karijere po svjetskim metropolama, dio života provodi u Južnoafričkoj Republici i Tajvanu. U mirovini se nastanjuje u Andori gdje se posvećuje literarnom radu objavivši tridesetak zbirki pjesama na trima jezicima - njemačkom, talijanskom i engleskom.

37 Muzur, A. (2013), 86.

38 Vio je svoje kulturne vidike formirao u predratnome razdoblju kao pripadnik talijanskoga nacionalnog bića, nastavljajući ih razvijati nakon rata u uvjetima kada taj isti nacionalni trenutak poprima sasvim novo značenje. U autobiografskom romanu Stranputice slobode čitatelj može iščitati poziciju pojedinca, kao i položaj ukupnoga manjinskog korpusa u gradu (Vio, Erik (1997). Stranputice slobode, Rijeka; Naklada Matice hrvatske). Vidi u: Lazzarich, Marinko (2016), Erik Vio, riječki kirurg na raskrižju povijesti, Acta medico-historica Adriatica, 14 (1), 145-160.

39 Muzur, A. (2013), 131-135.

40 Kada spominjemo neobične sudbine riječkih medicinara koji su svoj životni vijek proveli izvan rodnoga grada, svakako valja spomenuti otorinolaringologa Artura Maxera koji je u međuraću radio u Rijeci da bi nakon rata 1946. preselio u Trst. Fiziolog endokrinoga sustava Stevan Milković (1923. - 1989.) Sušačanin je koji ostvario zavidnu karijeru na zagrebačkom Farmeceutsko-biokemijskom fakultetu (Krvavica, 1990). Farmakolog Miroslav Mikuličić (1883. - 1955.), nakon mature u sušačkoj gimnaziji i studija medicine u Grazu, zapošljava se na Medicinskom fakultetu u Zagrebu. Njegova istraživanja u području 
Obojica vrhunskih medicinara osjetili su završetkom rata naturalističku determiniranost mjestom i vremenom življenja. "Vrijeme neposredno nakon prevrata 1945. bilo je djetinjstvo jednog novog društva izraslog na ruševinama riječko-sušačkog gospodarstva i trebalo je osigurati istodobno melem za rane tridesetogodišnjih političkih i ratnih turbulencija, izmjena vlada i granica, diktatura pjesnika i ricinusa, bombardmana okupatora i osloboditelja, depopulacije bijegom, selidbom i stradavanjem (praćene doseljavanjima poslije 1945.)." ${ }^{31}$ Razdoblje je to u kojem su stanovnici ovoga zemljopisnog područja prizivali u sjećanje glad i neimaštinu.$^{42} \mathrm{Krajem}$ rata Rijeku je napustila gotovo četvrtina žitelja. ${ }^{43}$

\section{Braća PAMich na RASKrižju POVIJESTi}

U službenoj riječkoj medicinskoj historiografiji ne spominju se braća Pamich, zdravstveni djelatnici koji su uspješnu karijeru ostvarili izvan rodnoga grada. ${ }^{44}$ Kada su se njihovi roditelji $1947{ }^{45}$ odlučili optirati za Italiju, Giovanni je imao petnaest, a Abdon četrnaest godina. ${ }^{46}$ Iako još nisu bili

patofiziologije spavanja izazvala su veliko zanimanje u širim medicinskim krugovima. Vidi u: (Muzur, A. (2013). Možemo navesti i primjer životnoga odabira dr. Ante Došena, nekadašnjega studenta riječkoga Medicinskog fakulteta, koji je napravio svjetsku karijeru u području dječje psihijatrije u Nizozemskoj, postavši svojedobno predsjednikom Europske udruge za mentalno zdravlje osoba s mentalnom retardacijom. Vidi u: Čemeljić, Alen (2007). Vitez Ante Došen, Sušačka revija, 15 (60), 69-72.

41 Muzur, A. (2013), 136.

42 Štefan, Ivo (2015), Sjećanja na životne uvjete i krijumčarske prakse u Rijeci i Sušaku neposredno nakon Drugog svjetskog rata, diplomski rad, Filozofski fakultet Sveučilišta u Zagrebu (2015), http: //darhiv.ffzg.unizg.hr/ id/ eprint/ 5592/ 1/ Stefan, \%20Ivo_ Diplomski \% 20 rad.pdf (pristupljeno 28. veljače 2020.)

43 Prema službenoj evidenciji sredinom 1944. u Rijeci je živio 59251 stanovnik, a 31. svibnja 1945. ostaje njih 44 544. Vidi u: Moravček, Goran (2006). Rijeka između mita i povijesti, Rijeka; Adamić d.o.o., 153.

44 Pamichi su podrijetlom iz Žminja. Njihov djed Antonio Pamich krajem 19. stoljeća preselio se u Rijeku oženivši se Giulianom Salomon, s kojom je imao četvero djece. S majčine strane Giovanni i Abdon baštine hrvatske korijene - njihov djed Ivan Sušanj i baka Marija (rođ. Lučić) rođeni su u Kastvu. Djed se nastanio u Rijeci radeći kao uspješan građevinar i trgovac i osnovavši brojnu obitelj. Otac Giovanni školovao se na talijanskom jeziku, a njihova majka Irena (Erenia) pohađala je hrvatske škole na Sušaku. Giovanni je diplomirao na studiju ekonomije i komercijale na Sveučilištu u Trstu te je vodio podružnicu privatne građevinske tvrtke na Sušaku. Osim Abdona i Giovannija, Pamichi su imali još dvoje djece - sina Raoula i kćer Irmu.

45 Budući da u ljeto 1947. stupa na snagu klauzula o mirovnom ugovoru, taj dokument omogućuje Riječanima talijanske nacionalnosti da se odluče za talijansko državljanstvo i legalno presele u Italiju. Takva mogućnost postaje spasonosna opcija za većinu Fjumana koji su proživjeli krizu poslijeratnoga razdoblja te se nastavlja masovno iseljavanje domicilnoga stanovništva. Vidi u: Pupo, R. (2018).

46 Orisi životnih pregnuća dvojice Riječana u području medicinskih znanosti nastali su na temelju osobnih kontakata s Giovannijem i Abdonom Pamichem. 
punoljetni, samostalno su se upustili u opasnu avanturu prelaska državne granice bez osobnih isprava. U početku su živjeli u izbjegličkom kampu u Novari gdje su nastavili školovanje, a kada je otac 1948. pronašao prihvatljivo stambeno rješenje u Genovi, obitelj je konačno opet bila na okupu. ${ }^{47}$

\section{TORAKALNI KIRURG I ZNANSTVENIK}

Giovanni Pamich je u Genovi završio srednju školu, nakon čega je u istom gradu I950. započeo studirati medicinu na Medicinskom fakultetu. Da bi stekao određenu ekonomsku neovisnost, prihvatio je honorarni posao instruktora tjelesnoga odgoja u jednoj srednjoj školi. Diplomirao je I956. i kraće vrijeme stažirao u bolnici kao medicinski asistent, nakon čega je odslužio vojni rok u Ratnoj mornarici (Accademia Navale) u Livornu, odakle je u lipnju I959. otpušten u zvanju poručnika. Prvo profesionalno medicinsko iskustvo stječe u Švicarskoj: angažiran je kao pomoćni kirurg na Odjelu opće kirurgije Okružne bolnice Locarno pod vodstvom dr. Fritza (Federica) Andina, pod čijim je strogim nadzorom svladavao osnove kirurgije. Andina je bio učenik glasovitoga Ernsta Sauerbrucha iz Klinike Berlin-Charlottenburg, prvoga liječnika koji je prakticirao torakalnu kirurgiju bez primjene hiperbarične komore. $^{48}$

Pamichu je nakon uspješne suradnje u timu dr. Andina ponuđeno mjesto viceprimarija na Odjelu kirurgije Kantonalne bolnice Bellinzona koju je vodio dr. Clemente Molo. Budući da je Molo neko vrijeme radio na Klinici za kirurgiju Sveučilišta u Zürichu, tijekom boravka u Bellinzoni Pamich je ostvario dobru suradnju s tamošnjim kirurškim timom Allgemeine Osteosynthese i grupom liječnika koji su među prvima razvili postupak izvođenja operacije osteosinteze unutar 24 sata od ozljede. U Švicarskoj je, dakle, stekao potrebno iskustvo, što mu je omogućilo da dobije posao u Italiji. Najprije se ig64. zaposlio u Bolnici Palmanova (Udine) na Odjelu za kirurgiju, a dvije godine

47 Po završetku rata očeva je podružnica nacionalizirana jer je nova vlast nastojala ugasiti sve privatne tvrtke u Rijeci. Budući da se obitelj nije mogla prilagoditi novom režimu, odlučili su se optirati za Italiju. Majka koja je ostala u Rijeci s dvoje najmlađe djece u dobi od tri i deset godina, nakon dugog i mučnoga birokratskog procesa pridružila se obitelji u Genovi godinu dana poslije, 1948. Obitelj simbolično predstavlja društvo u cjelini jer obitelj na specifičan način odražava zbivanja u čitavom kolektivu. Književnik Nedjeljko Fabrio to je sugestivno predočio u svome romanu Vježbanje života. Svi su njegovi likovi uvučeni u povijesni vrtlog, političke igre i bez obzira na to kojoj nacionalnosti pripadali, završit će tragično. Stoga je riječ o gubitnicima rođenim u pogrešno vrijeme. Fabrio, Nedjeljko (1986). Vježbanje života, Zagreb; Globus, Rijeka; Otokar Keršovani.

48 Fritz Andina surađivao je i s prof. Sanvenerom Rossellijem iz Milana, svojedobno jednim od najpoznatijih međunarodnih plastičnih kirurga. 
poslije prihvaća poziv ravnatelja bolnice u Monfalconeu u kojoj također obnaša djelatnost pomoćnoga kirurga.

Giovanni Pamich profesionalno je iskustvo stjecao i u Engleskoj gdje je specijalizirao torakalnu kirurgiju. Godine I969. boravi na Odjelu torakalne kirurgije Bolnice Maidstone (Kent), u okrugu Općega medicinskoga vijeća Londona (General Medical Council). Specijalizacija je protekla pod mentorstvom dr. Golebiowskog, nekadašnjega ratnog liječnika u stožeru generala Wladislawa Andersa, heroja bitke za Anconu i oslobođenje Talijanskoga poluotoka. Tijekom boravka u Engleskoj Pamich je nazočio operacijama u londonskome bolničkom centru Hammersmith Teaching Hospital.

Pet godina poslije, 1974., položio je državni ispit za primarnoga kirurga u Rimu. Iste godine povjereno mu je upražnjeno mjesto primarija u Bolnici Monfalcone. Slijedile su godine intenzivnoga rada jer je bolnici u lučkome gradu s brodogradilištem međunarodnoga značenja i razvijenom industrijom, u blizini regionalne zračne luke i autoceste Trst - Venecija, inkliniralo mnogobrojno stanovništvo Trsta, Udina i čitave regije Friuli. Strateški položaj grada dovodio je u bolnicu pacijente iz cijeloga svijeta. Kada je započeo upravljati Odjelom za kirurgiju, njegov je tim imao dvanaest liječnika, a kapacitet odjela iznosio je r6o kreveta. Osim većih trbušnih i torakalnih kirurških zahvata, izvođene su urološke operacije i dječja kirurgija jer su ta dva odjela bila objedinjena u Odjel za kirurgiju.

Nakon toga od 1991. do 1995. bio je šefom Odjela opće kirurgije bolnice u Gorizi, potom se ponovno vraća u Monfalcone i posljednje godine prije umirovljenja radi kao primarij i predstojnik Odjela opće kirurgije u Bolnici San Polo u Monfalconeu.

Stekavši auru vrhunskoga liječnika, uz posao u bolnici paralelno se od 1986. bavio istraživačkim radom kao sveučilišni profesor na Visokoj školi za specijalizaciju vaskularne kirurgije Sveučilišta u Trstu. Bilo je sasvim logično sve opsežniju i intenzivniju kiruršku aktivnost nadograditi znanstveno-istraživačkim radom: sudjelovanjem na nacionalnim i međunarodnim kongresima, znanstvenim radionicama i poslijediplomskim aktualizacijama u raznim centrima radi stjecanja znanja o novim kirurškim metodama i novim medicinskim instrumentima. Objavio je tridesetak znanstvenih radova u medicinsko-znanstvenim časopisima.

$\mathrm{Na}$ Visokoj školi za specijalizaciju vaskularne kirurgije Sveučilišta u Trstu stekao je znanstveno-nastavno zvanje izvanredni profesor. Umirovljen je r999. godine. 
U četrdeset godina medicinskoga staža Giovanni Pamich obavio je tridesetak tisuća operacija, od kojih su mnoge bile visokorizične, na svim poljima: trbušnoj, torakalnoj, vaskularnoj, urološkoj, traumatološkoj i endokrinoj. Znanje koje je baštinio od dvojice švicarskih mentora, stečeno iskustvo u praksi i cjeloživotno obrazovanje nagradili su ga mnogobrojnim sveučilišnim specijalističkim diplomama: iz opće kirurgije na Sveučilištu u Padovi, torakalne kirurgije Sveučilišta u Bologni, ortopedije i traumatologije Sveučilišta u Modeni. Sve to omogućilo mu je da kao kirurg intervenira na gotovo svim organima ljudskog tijela. Kao vrhunski kirurg i znanstvenik bio je članom brojnim medicinskih asocijacija i udruga, među kojima Talijanskoga društva za kirurgiju, Talijanskoga društva torakalne kirurgije te Međunarodne udruge kirurga u Evanstonu (SAD). Dobitnik je značajnih priznanja: La Rocca d'Oro (Zlatna tvrđava) Grada Monfalconea i ordena Vitez Republike kojim ga je odlikovao talijanski predsjednik.

Završetkom radnoga staža oduševljeno se posvetio drugom, pomorskom pozivu. Još 1967. položio je državni ispit za zvanje liječnika u pomorstvu. Osjećajući unutarnji zov mora i svojevrsnu potrebu za bijegom, godinama je obnašao dužnost službenoga liječnika Talijanske trgovačke mornarice (Marina Merkantile) kao zdravstveni ravnatelj na putničkim brodovima. Slične je poslove povremeno obavljao u mladosti tijekom praznika. Osim Mediterana, proputovao je Ameriku i Oceaniju. Početkom novoga tisućljeća prekooceanske putničke plovidbe više nisu bile redovite u Italiji te se Pamich odlučio za krstarenje morem pod različitim zastavama - liberijskom, panamskom i grčkom. Prema vlastitu priznanju, tražio je "prostor stabilnosti i slobode ...", kako je pisao Viktor Hugo, našavši ga u prostranstvu mora na velikim bijelim brodovima.

Rodni grad doživljava svojom kolijevkom (raz)otkrivajući tako duhovno stanje jednog esula lišenoga svojih korijena: ...ondje sam proveo sretne godine svoga prvog i drugog djetinjstva, prekinute krvavim i okrutnim ratom čije sam razorne učinke doživio još uvijek nezrelim očima, ali su ostavili neizbrisive tragove u mojoj svijesti. Ondje su se rodila prva prijateljstva s dječacima različitoga podrijetla - prijateljstva koja su mi još uvijek živa u sjećanjima - kao i sjećanje na grad koji je bio mikrokozmos u kojem su u potpunom skladu živjeli brojne kulture, jezici i religije." ${ }^{+49}$

49 U originalu: ... là trascorsi gli anni felici della prima e della seconda infanzia, interrotti da una guerra cruenta e crudele di cui vidi gli effetti devastanti con occhi ancora troppo acerbi; effetti che hanno lasciato segni indelebili nella mia mente. In quel contesto nacquero le prime amicizie con ragazzi dalle più varie origini - amicizie tuttora vive nei miei ricordi - e mi è rimasta nel cuore la memoria di una città che era un microcosmo in cui convivevano numerose lingue, culture e religioni in completa sintonia. Duca, Renato (2019), Giovanni Pamich, Fuga per la libertà, 
Po melankoličnom prizvuku ove su rečenice prispodobive sjetnom timbru autobiografske proze Paola Santarcangelija (1909. - I995.), Riječanina koji u svojoj knjizi Luka obezglavljena orla (Il porto dell'aquila decapitata, I988.) također tematizira raseljenost svojih sugrađana po svijetu. I Santarcangeli je duhovno povezan s prostorom svoga djetinjstva. ${ }^{50}$

Tragično iskustvo izmještanja iz rodnoga podneblja nije preobrazilo humanoga intelektualca, njegove uspomene nisu opterećene osobnom gorčinom nacionalne averzije. Dapače, svojim liječničkim etosom, predanim radom u medicini, ali i pomirljivim odnosom prema drugima, Giovanni Pamich izgradio je lik liječnika neopterećena politikom i rasnim pitanjima koji mogu zamutiti čovjekov svjetonazor. ${ }^{51}$ Suočen s vlastitim identitetom, ali i s drugim s kojima je dijelio životni prostor, u jednom se trenutku našao na raskrižju povijesti. Giovanni Pamich svojevrsni je apatrid izmješten iz vlastite sredine.

\section{SPORTSKI PSIHOLOG VRHUNSKIH NATJECATELJA}

Abdon Pamich rođen je u Rijeci 1933. godine. Studirao je sociologiju i psihologiju u Italiji, a nakon diplome specijalizirao je psihologiju sporta. Zaposlivši se kao službenik multinacionalnih i drugih javnih poduzeća, istodobno se posvetio atletici i brzom hodanju. Stečena znanja na studiju psihologije i sociologije praktično je primjenjivao u području sporta. ${ }^{52}$ Koristeći se znanstvenom metodologijom kroz savjetodavnu praksu, Pamich

http://www.imagazine.it/notizie-trieste-gorizia-udine-friuli/6938/ (pristupljeno 12. siječnja 2020.)

50 U piščevim uspomenama lučki grad zauzima posebno mjesto: ...Sasvim je posebna izgleda kao i mnoga druga naša mjesta i stvari - mili Kvarnerski zaljev, ponajviše zbog toga što bi neupućen čovjek mogao pomisliti da je riječ o jezeru (...) Naš je život bio usklađen s morem onako kako nikada nisam vidjeo ni u jednom gradu uz more, ili možda jesam samo u Veneciji, ali tamo, razumljivo, na drugačiji način. Pomorski značaj Rijeke iskazivao se njezinim neprestanim dodirom uz more. Santarcangeli, Paolo (2010). Luka obezglavljena oral, Rijeka; Izdavački centar Rijeka, 14.

51 U jednom je intervjuu na upit novinara što bi poručio mladima, odgovorio: Savjetovao bih im da se školuju kako bi imali određeni stupanj kulture koja će im pomoći da razaberu istinu od laži, kako ne bi bili manipulirani lažnim prorocima, prerušenim u spasitelje čovječanstva (...) da otvore svoj um ne podliježući tuđim utjecajima i obrate pozornost vlastitim osjećajima po kojima će dosegnuti slobodu misli, rasterećeni nacionalističkih onečišćenja, poštujući kulturu, religije i jezike drugih ljudi. Trajno pamtim riječi velikoga mislioca Immanuela Kanta: "Moja sloboda završava tamo gdje započinje sloboda drugih." Za razliku od Odiseja, sudbina je uskratila Giovanniju povratak 'svojoj Itaci', ali ne i njegovim roditeljima koji su pokopani na riječkom groblju Kozala, Duca, Renato (2019), Giovanni Pamich, Fuga per la libertà, http://www.imagazine.it/notizie-trieste-gorizia-udine-friuli/6938/ (pristupljeno 12. siječnja 2020.). Sinovi su ispunili zavjet dan svojim roditeljima, čemu svjedoči natpis uklesan na njihovoj grobnici: Sono ritornati a casa (Vratili su se kući).

52 Psihologija sporta posebna je znanstvena disciplina u okviru psihologije budući da koristi i primjenjuje psihološka načela i metode rada u području tjelovježbe i sportskih aktivnosti. Obuhvaća znanstveno proučavanje psiholoških čimbenika povezanih sa sportskom izvedbom, vježbanjem i drugim tjelesnim aktivnostima. Ova grana psihologije proučava 
je nastojao uključiti spoznaje psihologije u konkretnoj sportskoj disciplini, vodeći računa o interdisciplinarnome pristupu treningu i sportašima. ${ }^{53} \mathrm{Na}$ vlastitu je iskustvu shvatio značenje dobre mentalne pripreme - iako snažan natjecateljski duh podiže kompetitivnost sportaša, nije uvijek jamstvo vrhunskih performansi. Najbolje je rezultate postigao u radu s tenisačicama i rukometašima.

Polovicom osamdesetih godina ponuđena mu je suradnja s trima darovitim talijanskim tenisačicama: Sandrom Cecchini, Raffaellom Reggi i Laurom Garone. Pomnim psihološkim pripremama uspio je djevojkama podići samopouzdanje i vjeru u vlastite mogućnosti, ponajviše Sandri Cecchini ${ }^{54}$ Sve tri tenisačice postigle su velik uspjeh na Roland Garrosu 1985. godine..$^{55}$ Utjecaj iskusnog Abdona Pamicha nije bio zanemariv. U radu s tenisačicama inzistirao je na podizanju psihološke stabilnosti i učvršćivanju njihova odnosa sa svojim trenerima. ${ }^{56}$

Znajući da mnogi sportaši imaju poteškoća s koncentracijom uoči i za vrijeme natjecanja, pažljivo je kreirao treninge i situacije za poboljšanje mentalne dimenzije mladih atleta. Vježbao ih je pravilnom pristupu predstojećim izazovima na sportskom borilištu, ispravnom načinu razmišljanja i postupanju u napetim situacijama. Mudro je objedinio svoje stručno znanje psihologa s proživljenim iskustvom vrhunskoga atletičara. U radu s mladim

psihičke procese s ciljem predikcije i kontrole mogućih učinaka. Vidi na: http://www.ponder.hr/index.php/sportska-psihologija (pristupljeno 18. ožujka 2020.)

53 Svjestan u kojoj mjeri mentalni trening pridonosi uspjesima vrhunskih sportaša, razvio je specifičan pristup mentalnom treningu. Kao europski, svjetski i olimpijski prvak znao je da trema i natjecateljski stres mogu pogubno utjecati na psihu sportaša jer vrhunski sport, osim fizičkih ozljeda, može nanijeti štetu i umu.

54 Sandra Cecchini bila je prva Talijanka koja se plasirala u četvrtzavršnicu jednoga Grand Slam turnira. Uspjelo joj je to u dobi od dvadeset godina, kada je zaustavljena od tadašnje najbolje tenisačice svijeta, Martine Navratilove. Laura Garrone je 1985. osvojila juniorske turnire Roland Garros i Us Open. Raffaella Reggi je 1985. osvojila državno prvenstvo u Tarantu i igrala finale Barcelone. Sljedeće godine osvojila je US Open u kategoriji mješovitih parova, sa Španjolcem Sergiom Casalom, čime je postala prva Talijanka koja je osvojila Grand Slam. Vidi na: Scanagatta, Ubaldo (2013), Tutte le prime volte dell'Italrosa, Ubitennis, https://www.ubitennis.com/sport/tennis/2013/10/31/974878-utte_prime_volte_dell_italrosa.shtml (pristupljeno 12. ožujka 2020.)

55 Talijani dotad nisu imali tri predstavnice u glavnom dijelu turnira. Iako je strpljivo i predano radio s djevojkama, Pamich je u tisku izjavio kako je ovaj uspjeh pravo iznenađenje i nije očekivao tako brzu pozitivnu reakciju natjecateljica na zemljanim terenima Roland Garrosa.

56 Budući da su djevojke uglavnom izbivale iz roditeljske kuće podižući formu na dugotrajnim pripremama u Sjedinjenim Američkim Državama, Pamich je isticao da mladim djevojkama treba podrška kako bi izdržale izazove profesionalnoga sporta i života odvojenog od svoje obitelji. Martucci, Vincenzo (1985). Parigi ci ha rivelato tre "leonesse", Gazzatta dello Sport, 7. srpnja 1985., 47. 
tenisačicama i rukometašima usredotočio se na smanjenje tjeskobe i treme uoči nastupa te upravljanja stresom kako bi koncentracija u presudnim trenucima bila na dostatnoj razini. ${ }^{57}$ Kao mentalni trener vrhunskih sportaša poticao je svoje učenike na međusobnu suradnju i otvorenost u komunikaciji. Dakako da se njegov individualni pristup tenisačicama razlikovao od onoga prema rukometašima budući da je rukomet timski sport.

Pamich je pridonijeo neočekivanu uspjehu talijanske rukometne reprezentacije 1997. godine. Rukometni "autsajderi” uspjeli su se samo dvaput plasirati u završnicu značajnijih natjecanja. ${ }^{58} \mathrm{Kada}$ su prvi put ušli u završnicu svjetskoga prvenstva u rukometu i997. u tisku je objavljen članak pod naslovom Un sogno iridato (San u duginim bojama, Poto, 1997.). Prvenstvo je održano u Japanu, a Italija je od 24 ekipe završila natjecanje na osamnaestom mjestu. ${ }^{59}$ Nacionalni tim Italije vodio je Lino Červar, budući olimpijski i svjetski prvak. ${ }^{60} \mathrm{U}$ stručnom stožeru hrvatskoga trenera Pamich je bio važna karika kao sportski psiholog, pridonijevši svojim iskustvom povijesnom uspjehu talijanskoga rukometa. ${ }^{61}$

Timski je sport dobra prigoda za učenje o međuljudskim odnosima, disciplini, poštovanju suigrača, protivnika, momčadske hijerarhije, ne samo u sportu već i u životu. U tom je kontekstu Abdon Pamich djevojkama i mladićima bio pravi životni učitelj jer ih je upoznavao s metodama koje mogu postati vrijedni alati za suočavanje sa životnim izazovima.

57 Emocionalni naboj katkad može biti kontraproduktivan i Pamich je nastojao iskoristiti intelektualni potencijal svojih učenika u sportskoj realizaciji svojih ciljeva. Osim fizičkoga tonusa, uspjehu može pridonijeti i mentalna napetost samo ako se pravilno kanalizira. Smiren i predan svome poslu, Pamich je individualno pristupao tenisačicama i rukometašima znajući da svaki sportaš posjeduje osobni karakter i nije ih u psihološkoj domeni moguće jednako motivirati i trenirati. Tragao je za primjerenim metodama smirivanja tenzija pa je potencirao vježbe za mjerenje razine natjecateljskog naboja i održavanje koncentracije. Učio je svoje sportaše strategijama spontanoga smanjenja stresa, da se oslanjaju na određene geste i zadržavaju svoju koncentraciju određenim ritualima.

58 Valja istaknuti da rukomet nije nacionalni sport na Apeninskom poluotoku, stoga je rukometna reprezentacija Italije godinama jedna od najslabijih u Europi. U završnicu svjetskoga prvenstva talijanski su se rukometaši plasirali samo jednom, 1997., nakon što su u kvalifikacijama eliminirali Sloveniju, Švicarsku i Austriju.

59 Talijanski su rukometaši upisali jednu pobjedu nad Argentinom, remi s Norveškom te poraze od Švedske i Južne Koreje i budućih prvaka, rukometaša Francuske. Sljedeće je godine Italija bila domaćin završne faze Europskoga prvenstva u Bolzanu i Meranu, kvalificiravši se kao zemlja domaćin. Azzuri su završili na pretposljednjemu mjestu.

60 Nakon toga rukometna reprezentacija Italije nikad se više nije uspjela plasirati u završnicu europskih i svjetskih prvenstava. Vidi na: https://www.wikiwand.com/it/Nazionale_di_ pallamano_maschile_dell\%27Italia (pristupljeno 12. ožujka 2020.)

61 Staloženi je trener znao da je u rukometu konkurencija u momčadi snažno naglašena, ali ako se pravilno usmjeri može postati dragocjena energija i izvor uspjeha. 


\section{Narativni Realizam ili POVijest KaO Životna sudBINA}

Pozicija autohtonih stanovnika i sudionika minulih zbivanja u tekstovima riječkih pisaca na talijanskome jeziku ne dovodi u pitanje autentičnost njihove naracije. Osim profesionalnih književnika, temom egzodusa pozabavili su se i pojedinci različitih struka, između ostalih i Abdon Pamich. Knjiga Abdon Pamich, memorie di un marciatore, koju je uredio Robert Covaz, uzbudljiva je biografija riječkoga esula. ${ }^{62}$ Motriti nam je problematiziranje motiva raseljenosti u kontekstu literature granice. ${ }^{63}$

Nakon dolaska u Italiju Abdon je započeo trenirati atletiku s bratom Giovannijem. Dvojica mladića zarana su pokazivala darovitost u disciplini brzoga hodanja. S vremenom Abdon je postao najtrofejnijim talijanskim atletičarom. Daroviti je sportaš sudjelovao čak na pet olimpijskih igara $u$ utrci na 50 kilometara. Na Olimpijadi u Rimu i960. osvojio je brončanu medalju, a u Tokiju i964. napravio je pravi podvig osvojivši zlatnu olimpijsku medalju, što je bio vrhunac njegove sportske karijere. U dvadesetak godina aktivnoga natjecanja ostvario je zavidan broj pobjeda i titula, čime se može pohvaliti tek manji broj sportaša. ${ }^{64}$

Realistički prozni tekst (raz)otkriva čitatelju lik neumornoga sportaša sklona razmišljanju, veoma kompetitivnog u nadmetanju sa svojim suparnicima, štopericom, ali i s životnom odisejom. Ozbiljnije se posvetio sportu u dobi od devetnaest godina potvrdivši u ustrajnom odnosu prema treningu i napornom vježbanju nepokolebljiv karakter borca koji ne odustaje. ${ }^{65} \mathrm{I} u$

62 Covaz, Roberto (2016). Abdon Pamich, memorie di un marciatore, Pordenone; Edizioni Biblioteca dell Immagine. U knjizi nalazimo brojne motive egzilne književnosti: ratne opise razorenoga grada 1944., bombardiranja luke, dolazak doseljenika u Rijeku po završetku rata i odlaske domicilnoga stanovništva nakon 1945., represije novouspostavljenoga političkog režima... Obitelj Pamich u izbjeglištvu proživljava vrlo teške trenutke, stalno mijenjajući mjesto boravka.

63 Lazzarich, Marinko (2018), La storia come destino di vita - Abdon Pamich, memorie di un marciatore, Fiume, rivista di studi adriatici, 38 (2), 115-124.

64 Od uspjeha na velikim natjecanjima valja izdvojiti tri zlatne medalje na mediteranskim igrama (Barcelona, 1955., Napulj, 1963. i Smirna, 1971.), dvije zlatne medalje na europskim prvenstvima (Beograd, 1962., Budimpešta, 1966.) i jednu srebrnu medalju (Švedska, 1958.). Na olimpijskim igrama nastupio je pet puta, ali je najveći uspjeh zabilježio u Rimu, 1960. (brončana medalja) i u Tokiju, 1964. (zlatna olimpijska medalja). U Rimu je 1961. postigao svjetski rekorder u brzom hodanju na 50 kilometara (4 h 14"02"). Osvojio je čak 14 naslova prvaka Italije u brzom hodanju (1956. - 1969.). U dugoj 23-godišnjoj karijeri osvojio je mnoštvo odličja, što ga svrstava u najtrofejnije talijanske sportaše.

65 U osjetljivome životnom razdoblju sport mu postaje najvažnija aktivnost. Atletika mu je podarila mnogobrojne nezaboravne trenutke: susret s trenerom Giuseppeom Malaspinom koji će presudno utjecati na njegovu karijeru, antagonizam s velikim rivalom Giuseppeom Dordonijem, sudjelovanja na velikim natjecanjima i velike uspjehe u maratonu. Pamich postaje ključna figura na velikim natjecanjima i osvajač najsjajnijih odličja. Uspjesi su se 
kriznim trenutcima Pamich uspijeva pronaći snagu za nadvladavanje osobnih dvojbi. Iskreno priznaje da mu je sport obilježio život tako što mu je postao način života. ... Sport je za mene bio slobodan izbor, duhovna potreba, životna radost. ${ }^{66}$ Zahvaljujući sportu upoznao je mnoge poznate ličnosti poput Mike Bongiorna, pape Pavla VI., maršala Tita, Fidela Castra...

Uz retrospektivu sportskih događaja i opise karijere maratonca, Pamich navodi i prijelomne društvene događaje u drugoj polovici dvadesetoga stoljeća. Zanimljiva su njegova promišljanja o Rimu, o fijumanstvu i životu u istočnom bloku. Svjestan je svojih korijena, svoga podrijetla i specifičnosti pograničnoga područja. Promatra grad "izvana", kroz prizmu talijanskih mjesta u kojima živi i traga za zrcalnim odrazom Rijeke, dekonstruirajući i demistificirajući povijest. Najviše mu nedostaje more: ... Nakon Božića vratili smo se u Novaru. Život u gradu bez mora i bez planina stvarao je osjećaj kao da sam u pritvoru. Nedostajao mi je osjećaj slobode i beskraja koji sam proživljavao svaki put kad bih se približavao luci, onom moru pred kojim sam zamišljao da ostvarujem sve svoje snove iz djetinjstva i u kojem sam utapao adolescentske nemire. ${ }^{67}$

Talijanska ljetovališta na njega ostavljaju sasvim drukčiji dojam jer ga podsjećaju na rodni grad. Iznad svega Messina: ...činilo mi se da sam se vratio u kuću iza čijeg se prozora prostirao zaljev, sotokom Cresom koji je izgledao povezan s kopnom čineći obalnu cjelinu s Lovranom $i$ Opatijom. Bili su to vrlo intenziuni trenuci snažnih emocija, u kojima sam proživljavao cijeli svoj dotadašnji život, uranjajući u svoju nutrinu gdje sam se pronalazio i poimao smisao življenja. (Isto, 176). ${ }^{68}$

Slične motivske silnice pronalazimo i u tekstovima drugih riječkih esulskih književnika, poglavito u proznim zapisima Marise Madieri. ${ }^{69}$ Njezin

izmjenjivali s teškim trenutcima: ozljedama, amaterskim pristupom profesionalnom sportu, pripremama za velika natjecanja, neprospavanim noćima, nervozom uoči utrka, kao i pobjedama nad nenadmašenim protivnicima...

66 ... Lo sport per me è stato una libera scelta, un bisogno dello spirito, una gioia di vivere. (Covaz, R. (2016), 62).

67 U originalu: ... Dopo Natale tornammo a Novara. Vivere in una città senza mare e senza monti mi faceva sentire come in prigione. Mi mancava quella sensazione di libertà e di immenso che provavo tutte le volte che mi affacciavo sulla distesa marina, quel mare davanti il quale immaginavo di realizzare tutti i miei sogni infantili e nel quale affogavo tutte le malinconie di adolescente. (Isto, 52).

68 U originalu: ... Mi sembrava di essere ritornato in quella casa dalle cui finestre, da ragazzo, spaziavo sul golfo, con l'isola di Cherso che sembrava congiungersi con la terra ferma facendo un tutt'uno con la costa di Laurana ed Abbazia. Erano momenti molto intensi, di grande commozione, in cui rivivevo tutta la mia vita passata, immergendomi nella mia interiorità in fondo alla quale ritrovavo me stesso e il significato di esistere. (Isto, 176).

69 Nostalgična autobiografska proza Riječanke Marise Madieri (1938. - 1996.) spada u fundus fluminensie, književnosti posvećene riječkom podneblju. Madieri je kao djevojčica doživjela Drugi svjetski rat u Rijeci, sazrijevši u izbjegličkom stacionaru. Jednostavnim i neposrednim izrazom u romanima Zelena voda (Verde acqua, 1987.) i Ravnica (La radura, 
autobiografski roman Vodnozeleno (Aqua verde, Einaudi, Torino, 1998, GZH, Zagreb, I990.) lirska je evokacija izgubljena zavičaja. ${ }^{70}$

Pamich je svjestan svojih korijena, razmišlja o svojim sugrađanima i specifičnostima pograničnoga prostora. Kroz naraciju čitatelj dobiva sliku o čovjeku čvrsta karaktera kojem ispitivanje granica vlastite izdržljivosti postaje istinski izazov ("znatiželja je veća od treme"). ${ }^{71}$ Smireni "maratonac" nikada nije zaboravio trauma iz djetinjstva, suočavanje s ekstremnom ratnom situacijom i poslijeratnom migracijom. Abdon se, kao i njegov brat Giovanni, osjeća svojevrsnim apatridom jer poput brojnih raseljenih Fijumana nije uspio istisnuti rodno mjesto iz svoje duše. Suočen s egzistencijalnim pitanjima, sociološkim promjenama i ljudskim bezumljem, odlučuje se za život u talijanskoj metropoli.

Posljednje stranice posvećuje rodnom gradu. Nakon 67 godina, prvi put se 20I4. vraća u grad na Kvarneru i u društvu svoga brata Giovannija obilazi rodnu kuću. Citira riječkoga književnika Osvalda Ramousa: Città mia e non mia... (Grad moj, i koji to nije ....). ${ }^{72}$ Osjeća nemir i klonuće susreta s domom u kojem je odrastao: ... Naše srce zauvijek je ostalo u Rijeci gdje smo rođeni, i nikada nije pronašlo svoj mir... ${ }^{73}$ Dok promatraju dvorište svoga doma iz djetinjstva, jedna žena ih poziva da uđu u zgradu i nudi im piće.

U tom sam trenutku shvatio da mi ljudi s granice imamo dvije duše zbog čega smo često izgubljeni u svijetu u kojem živimo. Moje su se dvije duše tada sjedinile

1992.), autorica evocira uspomene iz riječkoga poraća, mukotrpnoga izbjeglištva po graničnim logorima. Promišlja o rodnom gradu kroz prizmu Trsta u kojem živi te s mnogo kriticizma secira urbano tkivo Rijeke. U pozadini sjetnih dnevničkih zapisa ljeska se Jadransko more sa svojim bajkovitim lokacijama kao nezaboravna uspomena na ključno razdoblje autoričina života.

70 Pamichev je nostalgičan opis mediteranskoga areala veoma sličan Madierinom. Za usporedbu navodimo ulomak iz spisateljičinoga romana Verde acqua: ...Bila sam veća, zamišljenija i zrelija. Tako se sjećam moje Rijeke - njezinih širokih obala, svetišta na trsatskom brežuljku, kazališta Verdi, središta s mračnim zgradama, Kantride - grada prisnosti i odstojanja, koji sam morala izgubiti tek što sam ga upoznala. Pa ipak, ta su bojažljiva i kratka približavanja, prožeta zamahom i daljinom, na mene ostavila neizbrisiv trag. Ja sam još onaj vjetar s obala, one ulične svjetlo-sjene, oni natruli zadasi mora $i$ one sive zgrade. Mnogo godina nakon odlaska ne vidjeh moj grad pa sam ga gotovo $i$ zaboravila, ali, kad mi se opet pružila zgoda da prođem Rijekom $i$ onim dijelom obale što vodi Brestovi, gdje obično idemo na trajekt za Cres $i$ Lošinj, doživjeh jasan osjećaj vraćanja u svoju istinu. Pa ipak, ničega se, barem svjesno, nisam sjećala od Ičića, Mučića, Lovrana, Mošćenice, a tek malko Opatije i same Rijeke. To sam ja u biti nalazila sebe samu, promatrajući poput nekog zrcala, taj promjenljiv krajolik oprosta i ushita. Madieri, Marisa (1990). Vodnozeleno, Zagreb; Grafički zavod Hrvatske, 54.

71 U originalu: la curiosità è grande più dell 'ansia.

72 Ramous, Osvaldo (2008). Il cavallo di cartapesta, Rijeka; Edit.

73 ... Il nostro cuore è rimasto sempre nella Fiume dove siamo nati, e non ha mai trovato pace... (Covaz, R. (2016), 188. 
$i$ konačno sam oćutio da sam se vratio kući. Da, rana je još uvijek bila otvorena! Unatoč svemu, život se nastavlja. ${ }^{74}$

Pamich poput Santarcangelija, Vija i Madieri piše vrlo emotivne retke posvećene gradu koji je morao napustiti. U poznoj dobi svoga života uspijeva pronaći duševni mir i odgovore na pitanja koja si je postavljao tijekom života. Prozna je ispovijed o izgubljenom zavičaju iskrena i emotivna uz primjetnu dozu patetike koja ipak ne opterećuje iskaz. ${ }^{75}$

Za razliku od Fijumana koji su ostali u rodnome gradu i spremno prihvatili težinu ostanka, Pamichi su otišli iz grada svojih predaka priklonivši se koloniji raseljenih Riječana diljem svijeta, ne uspijevajući se osloboditi čvrste veze s prošlošću. Možemo, stoga, postaviti retorička pitanja o njihovim životnim odlukama: Je li pravi razlog napornih natjecanja i bezbrojnih Abdonovih maratona iskustvo zaborava, boli i proživljene traume u djetinjstvu kada je bio primoran napustiti svoj zavičaj i prijatelje? Nije li pravi razlog Giovannijevih plovidbi morem potraga za prostorom slobode u vodenom prostranstvu koje ga podsjeća na rodni grad? Bez obzira na to jesu li njihovi postupci motivirani mučnim iskustvom egzodusa ili ne, jedno je sigurno Pamichima se ne može poreći ozbiljnost motivacije i snagu doživljaja jer su rat i razvoj situacije u poraću kompromitirali njihove snove.

\section{ZAKLJUČAK}

Propitivanje povijesne zbiljnosti predmnijeva historiografsku utemeljenost studioznoga proučavanja svakodnevice. $U$ tom je pristupu važno upućivati na određena simptomatična mjesta društveno-političkih mijena i intruzija. Na taj se način upotpunjuje (samo)kritička funkcija povijesti koja "ponovno oživljava povijest na drugoj razini“, istodobno iscrpljujući stalno s novim objektima proučavanja. ${ }^{76}$

Budući da su tijekom povijesti u gradu dominantno egzistirale dvije kulture (slavenska i talijanska), Rijeka je često bila prizorište identitetskih sukoba. Burna politička previranja nakon Drugoga svjetskog rata rezultirala su migracijom domicilnoga stanovništva talijanske nacionalnosti. Neriješeni državnopravni status grada, diplomatske borbe, neriješeni nacionalni

74 U originalu: In quel momento ho capito che noi gente di frontiera abbiamo due anime e per questo, molte volte, ci sentiamo persi nel mondo in cui viviamo. In quel momento le mie due anime si sono riunite e mi sono sentito finalmente a casa. Sì, la ferita era ancora aperta! Nonostante tutto, la vita continua. (Isto, 188.)

75 Lazzarich, M. (2018).

76 Nora, P. (2007), 164. 
problemi i promjena društveno-političkog poretka bili su glavnim uzrocima posljedičnih migracija i ostaju zapamćeni traumatičnim iskustvom za „,malog čovjeka" onoga doba. ${ }^{77}$ Masovni je egzodus u kolektivnoj amnezi grada trajno ostavio ispražnjeno simboličko polje. ${ }^{78}$

Povijesnih intruzija na Kvarneru nije bila lišena ni medicinska struka. Među iseljenicima našli su se i znameniti liječnici Erik Vio i Giovanni Dalma, kao i mnogi drugi medicinari koji su ostvarili uspješne karijere diljem svijeta. U tekstu se govori kako o pojedinačnom, tako i o kolektivnom sjećanju. Kolektivitet se kao jedinstvena kategorija obično reflektira nasiljem nad svima koji ne zadovoljavaju postavljene kriterije. ${ }^{79}$

Knjiga Abdon Pamich, memorie di un marciatore dokumentirana je biografija koja pokušava rasvijetliti povijesni trenutak kada Rijeka iz temelja mijenja svoju socijalnu sliku. I ovaj diskurzivni zapis, kao i mnogi memorijalistički iskazi, svjedoči o terapeutskoj ulozi autobiografske naracije..$^{80}$ Abdon Pamich ne protivi se povijesnoj objektivnosti niti ju želi negirati, već se usredotočuje na one aspekte koje povijest (modelirajući opći okvir prošlosti) izostavlja. Riječ je o zasebnim sjećanjima, odvojenim od kontrasta između kolektivne i pojedinačne memorije. "Sjećanje je bilo - i ostaje bojno polje za emocije i razum ljudi." ${ }^{\prime 1}$ Knjiga govori o povijesti koja ubire svoj danak, a u svemu tome pati običan mali čovjek. Oni koji su proživjeli tragičnu kob izmještenoga bića znaju da spokoja nema bez boli i patnje. Bez obzira o čijem se rodoslovlju radi, na granicama svjetova grubo se prožimaju osobna i literarna iskustva. Knjiga se istodobno uklapa u korpus literarnih ostvaraja koji se posljednjih desetljeća bave ovom osjetljivom temom u svjetlu aktualnih europskih migracija. Ujedno potvrđuje tezu kako se priča o Rijeci i odnosu njezinih građana prema prošlosti može projecirati u svaku pograničnu sredinu bremenitu povijesnim sjećanjima.

77 Dukovski, D. (2011), 132.-133.

78 Pokazatelji praznoga mjesta su sporadična uporaba nekadašnjega službenog jezika i tradicijski višelturalni kontekst koji je dijelomice prihvaćen među pridošlim žiteljima. Nositelji nevidljivih mehanizama gradskoga života ostali su u manjini, ali je talijanska kultura prosvjetiteljski nastavila djelovati na slavenski svijet zagovarajući snošljiv suživot. Sorel, Sanjin (2004), Razdioba riječke poezije druge polovice XX. stoljeća, u: Kolo, 14, br. 4, Zagreb, str. 288-304.

79 Bhabha, H. (1990).

80 Lachmann, Renate (2007). Metamorfoza činjenica i tajno znanje, Sarajevo; Naklada Zoro. U nastojanju interpretacije prošlosti unutar autobiografskoga iskustva književnici obogaćuju svoj iskaz bolnom nostalgijom jer se u svojim tekstovima pozivaju na događaje kojih se Talijani nerado sjećaju.

81 Foot, J. (2009), 8. U originalu: La memoria era - e resta u un campo di battaglia per $i$ cuori e le menti delle persone. 
Poput povijesnih velikana iz svijeta, umjetnosti, znanosti i sporta braća Pamich karakterne su ličnosti koji su uspjeli nadvladati osobne traume preokrenuvši ih u svoju korist. Giovanni i Abdon Pamich iz vlastite tragedije crpe snagu za nove pobjede. Prvobitna je zavičajnost odigrala značajnu ulogu u profiliranju njihovih osobnosti: obojica su neraskidivo povezani sa svojim rodnim gradom koji ih je, ipak, presudno formirao. Suočeni s egzistencijalnim pitanjima i unatoč nepovoljnim egzilnim okolnostima ostvarili su u Italiji zavidne karijere na polju zdravstva i medicine - stariji brat Giovanni postao je uspješan kirurg, a mlađi Abdon psiholog. S obzirom na dob kada su napustili grad, njihove medicinske i sportske uspjehe ne možemo smatrati dijelom riječke povijesti medicine. Iako ne ulaze u korpus medicinske historiografije, njihova imena zaslužuju spomen u sklopu važne struke Luke različitosti. Možemo samo nagađati što bi se dogodilo da nisu otišli iz Rijeke 1947., i kako bi se njihove karijere razvijale da su kojim slučajem nastavili živjeti u matičnoj sredini. Njihov je život obilježen traumom izmještanja i nizom neobičnih čimbenika koji su ih u Italiji približili svijetu medicine i sportske psihologije. Sudeći po postignutom uspjehu, njihov prinos riječkoj medicini zasigurno ne bi bio zanemariv.

\section{IZVORI}

1. Covaz, Roberto (2016). Abdon Pamich, memorie di un marciatore, Pordenone; Edizioni Biblioteca dell Immagine.

2. Damiani, Alessandro (1996). La torre del borgo, Udine; Campanotto.

3. Fabrio, Nedjeljko (1986). Vježbanje života, Zagreb; Globus, Rijeka; Otokar Keršovani.

4. Madieri, Marisa (1990). Vodnozeleno, Zagreb; Grafički zavod Hrvatske.

5. Ramous, Osvaldo (2008). Il cavallo di cartapesta, Rijeka; Edit.

6. Santarcangeli, Paolo (2010). Luka obezglavljena oral, Rijeka; Izdavački centar Rijeka.

7. Vio, Erik (1997). Stranputice slobode, Rijeka; Naklada Matice hrvatske. 


\section{LiterATURA}

1. Bačić-Karković, Danijela (2008). Rijeka u priči: hrestomatija književnih tekstova o gradu na Rječini, Rijeka; Filozofski fakultet u Rijeci, Odsjek za kroatistiku.

2. Berlot, Duško (ur.) (1970). Rijeka, fotomonografija, Zagreb; Grafički zavod Hrvatske.

3. Bhabha, H. K. (1990). Nation and Naration, Routledge, London.

4. Brodski, Iosif (1992). Watermark, New York; Noonday Press; Farrar, Straus \& Giroux.

5. Connerton, Paul (2004). Kako se društva sjećaju, Zagreb; Izdanja Antibarbarus.

6. Čalušić, Barbara (2019), Vrhunski riječki liječnik otkrio kako je ugradio najmanji pacemaker na svijetu, http://www.novilist.hr/Vijesti/Rijeka/Vrhunski-rijeckilijecnik-otkrio-kako-je-ugradio-najmanji-pacemaker-na-svijetu.-Upoznajte-dr.Sandra-Brusicha/ (pristupljeno 7. ožujka 2020.)

7. Čemeljić, Alen (2007). Vitez Ante Došen, Sušačka revija, 15 (60), 69-72.

8. Čulinović, Ferdo (1953). Riječka država: od Londonskog pakta i Danuncijade do Rapalla $i$ aneksije Italiji, Zagreb; Školska knjiga.

9. Damiani, Alessandro (1991). La letteratura italiana in Istria prima e dopo l'esodo: i tratti di una continuitá, La Battana, 97-98, 184-196.

10. Duca, Renato (2019), Giovanni Pamich, Fuga per la libertà, http://www.imagazine.it/notizie-trieste-gorizia-udine-friuli/6938/ (pristupljeno 12. siječnja 2020.)

11. Dukovski, Darko (2011). Istra i Rijeka u prvoj polovici 20. stoljeća: (1918. - 1947.) Zagreb; Leykam.

12. Fabrio, Nedjeljko (2003). Ruža vjetrova, sjevernojadranski i drugi eseji, Zagreb; Naklada Ljevak.

13. Felman, Shoshana, Laub, Dori (1992). Testimony: Crises of Witnessing in Literature, Psychoanalysis and History, Routledge, London-New York.

14. Foot, John (2009). Frature d"Italia, Milano; Rizzoli.

15. Fučkar, Željko i sur. (2011). Povijest transplatacije bubrega u bolnici na Sušaku, Acta Medica Croatica, 65 (4), 323-328.

16. Ginzburg, Carlo (1989). Clues, Myths, and Historical Method, Baltimore; John Hopkins University Press.

17. Gruber, Franjo, Brajac, Ines, Stanić-Zgombić, Zrinka (2008). Giovanni Battista Cambieri and the Beginning of Venereology in Rijeka Region, Acta dermatovenerologica Croatica, 16 (1), 3-7.

18. Gruber, Franjo, Čabrijan, Leo, Vukas, Duje (2000). Prof. dr. Ante Vukas - pronalazač epidermotekstoskopije, Acta Facultatis medicae fluninensis, 25 (1-2), 77-78. 
19. Hall, Stuart (1996). Who Needs Identity, u: Hall, Stuart, du Gay, Paul ed., Questions of Cultural Identity. Sage, London, 1-17.

20. Jambrešić- Kirin, Renata (1995). Svjedočenje i povijesno pamćenje: o pripovjednom posredovanju osobnog iskustva, Narodna umjetnost - hrvatski časopis za etnologiju i folkloristiku, 32 (2), 165-185.

21. Krvavica, Slavko (1990). Stevan Milković, Ljetopis JAZU, 93, 404-406.

22. Lachmann, Renate (2007). Metamorfoza činjenica i tajno znanje, Sarajevo; Naklada Zoro.

23. Lazzarich, Marinko (2016), Erik Vio, riječki kirurg na raskrižju povijesti, Acta medico-historica Adriatica, 14 (1), 145-160.

24. Lazzarich, Marinko (2018), La storia come destino di vita - Abdon Pamich, memorie di un marciatore, Fiume, rivista di studi adriatici, 38 (2), 115-124.

25. Lehan, Richard (1998). City in Literature: an intelectual and cultural history, Berkeley / Los Angeles; University of Press.

26. Martucci, Vincenzo (1985). Parigi ci ha rivelato tre "leonesse", Gazzatta dello Sport, 7. 7. 1985., 47.

27. Moravček, Goran (2006). Rijeka između mita i povijesti, Rijeka; Adamić d.o.o.

28. Muzur, Amir (2013). Nezavršena povijest medicine u Rijeci. Priča o gradu, ljudima $i$ profesiji, Rijeka; Medicinski fakultet Sveučilišta u Rijeci, Hrvatsko znanstveno društvo za povijest zdravstvene kulture, Naklada Kvarner.

29. Nora, Pierre (2007). Između sjećanja i povijesti, Diskrepancija, 8 (12), 135-165.

30. Parnell, P. C. (1992). Time and Irony in Manila Squatter Movements, in: Nordstrom, Carolyn, Martin, Joann eds., The Paths to Domination, Resistance and Terror, University of California Press, Berkley, 154-176.

31. Pavlović, Predrag (2013). Profesor dr. sc. Drago Vrbanić - vrijedan doprinos razvoju onkologije u Rijeci, Acta medico-historica Adriatica, 11 (1), 165-168.

32. Perini, Giovanni (1949). Nel centenario della nascita di Antonio Grossich, Minerva medica, 40 (27), 1-8.

33. Petacco, Arrigo (1999). L'esodo, La tragedia negata degli italiani d'Istria, Dalmazia e Venezia Giulia, Milano; Mondadori.

34. Poto, Daniele (1997). Un sogno iridato, Maglia azzura, 24, 16-17.

35. Primc, Davor, Muzur, Amir, Doričić, Robert, Markić, Dean (2017). Novi prilozi o životu i radu Vinka Frančiškovića (1919. - 1984.) pionira kardiotorakalne i transplantacijske medicine u Hrvatskoj, Acta medico-historica Adriatica, 15 (1), 119-128.

36. Pupo, Raoul (2005). Il lungo esodo, Istria: le persecuzioni, le foibe, l'esilio, Milano; Rizzoli.

37. Pupo, R. (2018). Fiume città di passione, Laterza, Roma-Bari. 
38. Pužar, Aljoša (1999). Citta di carta / Papirnati grad, La letteratura italiana di fume nell Ottocento e nell Novecento, Rijeka; Edit Rijeka, ICR.

39. Rihtman-Auguštin, Dunja (1988). Etnologija naše svakodnevice, Zagreb; Školska knjiga.

40. Scanagatta, Ubaldo (2013), Tutte le prime volte dell'Italrosa, Ubitennis, https:// www.ubitennis.com/sport/tennis/2013/10/31/974878-utte_prime_volte_dell_ italrosa.shtml (pristupljeno 12. ožujka 2020.)

41. Sepčić, Juraj, Muzur, Amir, Tomić, Zoran, Popović, Katarina (2000). Lionello Lenaz i pojam statične inervacije mišićnog tonusa, Acta Facultatis medicae fluminensis, 25, 65-66.

42. Sequi, Eros (1953). Eravamo in tanti, Fiume / Rijeka; Edit.

43. ti. ca. (2006), Pamich: Il mio successore doveva essere Sottosanti, Il Piccolo, https://ricerca.gelocal.it/ilpiccolo/archivio/ilpiccolo/2006/11/10/MF_19_PAMI. html?refresh_ce (pristupljeno 28. veljače 2020.)

44. Sorel, Sanjin. Razdioba riječke poezije druge polovice XX. stoljeća, u: Kolo, 14, br. 4, Zagreb, 2004., str. 288-304.

45. Sportska psihologija; Standardi rada, http://www.ponder.hr/index.php/sportska-psihologija (pristupljeno 18. ožujka 2020.)

46. Štefan, Ivo (2015), Sjećanja na životne uvjete i krijumčarske prakse u Rijeci i Sušaku neposredno nakon Drugog svjetskog rata, diplomski rad, Filozofski fakultet Sveučilišta u Zagrebu (2015), http://darhiv.ffzg.unizg.hr/id/eprint/5592/1/ Stefan,\%20Ivo_Diplomski\%20rad.pdf (pistupljeno 28. veljače 2020.)

47. Trampus, Claudio (2010), Intervista a Marco Lo Duca, campione della Pallamano Trieste, portmagazinefvg.it/campione-in-primo-piano/sportivo-campione-coach-pallamano-intervista-marco-lo-duca/ (pristupljeno 12. ožujka 2020.)

48. Uremović, Vladimir, Mirošević, Lovro, Vukelić, Ivan (2006). Razvoj primaljskog školstva u Rijeci, Acta medico-historica Adriatica, 4 (1), 85-96.

49. Velčić, M. (1991). Otisak priče. Intertekstualno proučavanje autobiografije, August Cesarec, Zagreb.

50. Weeks, Jeffrey (1998). The Value of Difference, in: Jonathan Rutherford ed., Identity: Community, Culture, Diference; London; Lawrence \& Wishart.

51. Žic, Igor (2012). Paolo Santarcangeli i njegova autobiografska proza, Književna Rijeka, 4, 307-317. https://www.wikiwand.com/it/Nazionale_di_pallamano_maschile_dell\%27Italia/ (pristupljeno 12. ožujka 2020.) 


\section{Summary}

Medical history of the city of Rijeka is a rich treasure trove of events, celebrities and valuable innovations in the field of healthcare. The historical development of Rijeka was largely determined by her geopolitical position as a border town with a multicultural population, marked by strong conflicts of interest and numerous identity turmoil. The great exodus of the domicile population of Italian nationality after World War II has significantly changed the social picture of the city. Among many of such esuli (immigrants) were brothers Giovanni (b. 1932) and Abdon (b. 1933) Pamich, whose lives are reminiscent of the fate of many displaced people from Rijeka who were forced to live in exile after the war. After leaving their hometown during the formative years of their childhood, they had successful careers in Italy in the fields of medicine and healthcare. The older brother Giovanni became a successful surgeon and the younger Abdon a psychologist. Along with his positions as the head of general surgery at the Monfalcone and Gorizia Hospitals, Giovanni Pamich was teaching at the University of Trieste. Abdon Pamich collaborated with the best Italian tennis players in the field of sports psychology, and was a psychologist for the Italian handball team. They both practiced athletics, and Abdon Pamich won the silver medal in speed walking at the 1958 European Championships in Sweden and the gold medal at the 1964 Tokyo Olympics.

In addition to emphasizing the achievements of the two brothers in the field of medicine, this paper also addresses the position of the migrant, which is highlighted in Robert Covaz's book "Abdon Pamich, memorie di un marciatore (Rome, 20I6), an exciting biography of an emigrant from Rijeka. The paper also explores the concept of thematizing the limits of differences and experiences of migration of Rijeka residents facing the existential issues.

Keywords: Giovanni and Abdon Pamich, medicine, psychology, emigration, athletics, Rijeka history, Italy 